\title{
Varijabilna realnost Zapadnog Balkana u kontekstu evropske integracije
}

\author{
ALEKSANDAR ANDRIJA PEJOVIĆ \\ Pravni fakultet, Univerzitet u Beogradu
}

\begin{abstract}
Sažetak
Budućnost Zapadnog Balkana u svjetlu evropske integracije umnogome počiva na nizu različitih faktora koji nijesu dominantno i jedino vezani za same države ovog regiona. Iako sam proces integracije u EU presudno zavisi od spremnosti i sposobnosti država kandidata i potencijalnih kandidata da sprovedu sve potrebne reforme, transponuju pravnu tekovinu i ostvare tzv. evropski standard u zakonodavstvu i u praksi, on se ne odvija u vakuumu. Prije svega treba imati na umu da će razvoj situacije unutar Evropske unije imati značajnog uticaja na brzinu, dubinu i kvalitet ulaska preostalih balkanskih zemalja u Uniju. Evropska unija odnosno njezine države članice su te koje određuju i postavljaju pravila, te i snose najveću odgovornost za politiku proširenja. Pored toga ne smiju se zanemariti ni uticaji trećih strana koji su sve primjetniji i akutniji u regionu. Usporavanje reformi, evropsko upravljanje krizama, pojačana ili slabija uloga trećih aktera, sve to će bitno odrediti kakav proces evrointegracije predstoji u narednim godinama te, u skladu s time, i način na koji će on uticati na stabilnost i budućnost samih zemalja proširenja. $U$ tom smislu, Zapadni Balkan istovremeno živi u promjenljivim stvarnostima koje donose različite ishode i mogućnosti. Ovaj članak, pored pregleda stanja na Zapadnom Balkanu, stoga daje i moguće scenarije za budući period.
\end{abstract}

Ključne riječi: Evropska unija, Politika proširenja, Zapadni Balkan, treći akteri, Evropske integracije

\section{Uvodne napomene}

Od novembra 2000., kad je u Zagrebu zvanično predstavljen Proces stabilizacije i pridruživanja kao politički i finansijski okvir saradnje sa državama Zapadnog Balkana (Eur-lex, 2000), region je prošao kroz veoma složen i zahtjevan period transformacije. Proces stabilizacije i pridruživanja se, tako, tokom proteklih sedamnaest godina pokazao kao osnovni instrument koji omogućava da države regiona 
izgrađuju demokratske institucije, rade na vladavini prava i stvaranju održive, otvorene i napredne ekonomije, i konačno usklade svoje zakonodavstvo s pravnom tekovinom EU. Takođe, ovaj mehanizam je odigrao značajnu ulogu u vraćanju povjerenja, obnavljanju dobrosusjedskih odnosa i snaženju regionalne saradnje. Države Zapadnog Balkana su, tako, u kontekstu polaznih osnova prešle dug put od devedesetih, $u$ dijelu usklađenosti s evropskim standardima i vrijednostima, i pritom se perspektiva članstva u EU pokazala kao ključan mehanizam za podsticanje ukupnih reformi. Za razliku od država Istočne i Centralne Evrope, države Zapadnog Balkana su tako morale proći kroz značajno različit put koji je podrazumijevao prvo stabilizaciju, nakon toga pridruživanje, da bi se put mogao završiti pristupanjem Uniji. Ovo je vremenski značilo mnogo duži integrativni put, ali i potrebu da Evropska unija osmisli različit pristup i mehanizme kako bi dovršila proces integracije u Jugoistočnoj Evropi.

Proces stabilizacije i pridruživanja je, dakle, najznačajniji okvir kroz koji Evropska unija održava odnose s državama Zapadnog Balkana i kroz koji usmjerava svoju cjelokupnu politiku proširenja u ovom dijelu Evrope. On se zasniva na posebnim sporazumima o stabilizaciji i pridruživanju (SSP) koji su konsekutivno sklapani u rasponu od preko deset godina, prvi s Makedonijom, posljednji s Kosovom. Činjenica da je trebalo više od decenije da se oni sklope i stupe na snagu sa svima u regionu govori prije svega o razlici koja postoji u odnosu na ranija proširenja, ali i na veoma drukčiji karakter odnosa između EU i Zapadnog Balkana. Iako sporazumi ne garantuju i otvaranje pregovora o članstvu, ipak su dvije države dosad uspjele započeti ovaj proces, a sve ostale se spremaju da to urade u budućnosti. Evropska unija regionu, takođe, daje finansijsku podršku iz pretpristupnih fondova za projekte reformi zakonodavstva i izgradnju institucija (European Court of Auditors, 2016), ali i sve više za infrastrukturne projekte kroz Berlinski proces. Tokom proteklih sedamnaest godina dosta novca je uloženo u razne procese na Zapadnom Balkanu uz obećanje da će se ove investicije nastaviti i pored očekivanih problema u popunjavanju evropskog budžeta nakon izlaska Velike Britanije iz članstva u EU (Miščević, 2016: 11).

Međutim, kad sagledamo stanje u realnosti, vidimo da je napredak država neujednačen, kao i da su rezultati reformi, koje su u jednom periodu bile u zamahu, u međuvremenu u pojedinim državama posustali. Pored toga, zamor od daljih proširenja u EU koji je uslovljen oslabljenim apsorpcijskim kapacitetima Unije uslijed brojnih unutrašnjih i eksternih kriza $\mathrm{s}$ kojima se suočava posljednjih godina, ima uticaja i na stvaranje zamora od reformi odnosno integracijskog zamora u državama Zapadnog Balkana. U regiji tako više ne bilježimo svesrdnu podršku uz izuzetno visoke pozitivne stavove $u$ istraživanjima mišljenja javnosti u odnosu na EU i proces integracije (Gallup, 2017). Jasno je i da percepcija država Zapadnog Balkana među 
članicama EU nije na visokom nivou. Ona se uglavnom vezuje za ratove, siromaštvo i neuređenost odnosno negativni imidž zemalja kojima je potrebna pomoć i koje prave probleme. Posljednje istraživanje Eurobarometra iz novembra 2016. ${ }^{1}$ pokazuje da u prosjeku samo 39 posto stanovništva EU pozitivno gleda na dalje proširenje EU, dok je 51 posto negativno po ovom pitanju. Ovaj prosjek protivnika širenja je, štoviše, i nešto viši u državama eurozone - 56 posto ne želi nove članice u Uniji. ${ }^{2}$ Čak i ako se ima na umu da je Turska prva država na koju se pomisli kad se govori o proširenju, ni Zapadni Balkan nema mnogo pozitivniju reputaciju, osim u državama koje ga okružuju. Ipak, mnogo problematičnijom od samog stava javnosti u zemljama članicama se pokazala tzv. "nacionalizacija politike proširenja" (Hillion, 2010), kako Kristof Hilion još 2010. najavljuje ono što će danas biti sve primjetnije u novom valu proširenja. Sve veći uticaj država članica EU na politiku proširenja i odlučivanje u kontinuitetu dovodi do blokada, odlaganja i politizacije procesa na način da proširenje ne može evoluirati u jedinstvenu politiku. Iako mnoge države članice imaju svoj specifičan stav prema proširenju, najprimjetniji je svakako njemački. Berlin se posljednjih godina pozicionirao kao nezaobilazna adresa uz Brisel za bilo kakav razgovor o proširenju i daljem napretku bilo kojeg kandidata odnosno potencijalnog kandidata. Složenost odnosa među institucijama u Berlinu je proizvela tzv. politiku "da, ali” (Adebahr i Töglhofer, 2015: 39), koja isključuje automatizam ili obećanje bilo kakvog datuma uz mnoštvo dodatnih i detaljnih kriterijuma.

Proces proširenja preostalih zemalja Zapadnog Balkana, dakle, traje neravnomjernim tokom uz dosta zastoja koji onemogućava da se ostvari grupno pristupanje kakvo je karakterisalo dosadašnja pristupanja. Ono što predstoji Zapadnom Balkanu jeste jedan neizvjesni period integracije koji će zavisiti od niza faktora koji dominantno nisu vezani za samu regiju. Razvoj Evropske unije nakon martovskog samita u Rimu u povodu 60 godina Rimskih ugovora, proces izlaska Velike Britanije iz EU, uspješnost u rješavanju postojećih kriza i eventualno nove krize, sve će to imati reperkusije po sam proces pristupanja preostalog dijela Evrope koji je izvan EU, a u potpunosti okružen Unijom. Naravno, kapaciteti i predanost samih zemalja Zapadnog Balkana igraju značajnu ulogu u ovom procesu, ali odnos Evropske unije odnosno njezinih država članica je ključan. Bez jasne strategije i vizije kad i na koji način želi dovršiti proces integracije na Balkanu ne možemo govoriti ni o uspješnom radu i rezultatima država regiona. Politika proširenja je prošla kroz nekoliko faza, ali nikad dosad se nije nalazila u tako kompleksnom odnosu s internim problemima Unije, evroskepticizmom, geopolitičkim dešavanjima na obodima EU i ko-

${ }^{1}$ Istraživanje Standard Eurobarometer 2016, 86, Autumn 2016, dostupno na: http://ec.europa. eu/COMMFrontOffice/publicopinion/index.cfm/Survey/getSurveyDetail/instruments/STANDARD/surveyKy/2137, 27. 7. 2017.

${ }^{2}$ U Njemačkoj je 68 posto ispitanih protiv širenja EU, a u Austriji čak 71 posto. 
načno osjećajem da ne postoji jasna predstava o tome kuda, kako i kroz koje vrijeme treba razvijati ovu politiku. Aksel Valden sumorno naziva "grčkim kalendama" (Wallden, 2017: 22) ovaj otvoreni proces u kojem nema vizije ne samo za Zapadni Balkan, nego ni za Tursku, ali ni za Istočno partnerstvo. Da li se zaista radi o otvorenom procesu kojem nema kraja, da li je ovo samo pauza uz nedostatak odlučnosti da se iznađu novi modaliteti, datumi i jasni stavovi, ili je pred nama rješenje koje ne očekujemo? Situacija u kojoj se regija nalazi je neizvjesna i pred njome je nekoliko scenarija za naredni period. Svi će oni, bili realni ili manje realni, odrediti dešavanja u samim državama regije, ali i budućnost ovog regiona i politike proširenja EU. Prije svega, treba sagledati trenutno stanje i polazne osnove.

\section{Okvir pristupanja na Zapadnom Balkanu}

Države Zapadnog Balkana se danas nalaze u različitim fazama procesa evropske integracije. Kreću se različitim brzinama uz svoje posebnosti i veoma različite razloge iz kojih ne mogu ostvariti dinamičniji ritam ulaska u EU. Unutrašnji problemi, usporenost reformi, nedostatak volje ili mogućnosti da se nađu konkretna i održiva rješenja; sve je to prisutno na Zapadnom Balkanu i bitno utiče na sposobnost integrisanja. Dodatan razlog leži u tome što je politika proširenja postala mnogo zahtjevnija, a procedure složenije nego ranije, fokus je više na primjeni politika i rješenja, a ne samo na usvajanju pravnih i institucionalnih standarda. Takođe, važni razlozi leže u činjenici da je EU posljednju deceniju suočena s brojnim unutrašnjim i vanjskim problemima, poput uticaja globalne ekonomske i finansijske krize, migracija i porasta ekstremizma i radikalizma te odluke Velike Britanije o izlasku iz članstva. Poslije dugog vremena integracije EU se suočava i sa strahom od dezintegracije i potrebom da se preduzmu supstancijalne unutrašnje promjene koje će spriječiti njezinu dalju fragmentaciju. Takođe, EU se suočava s tendencijom rastućeg evroskepticizma u državama članicama - usponom populističkih i desničarskih partija; niskim nivoom ekonomskog rasta i institucionalnom neefikasnošću u sprovođenju evropskih standarda i vrijednosti.

Nakon 2000. i šanse da se sve države integrišu jednakom brzinom, uslijedio je period u kojem su unutrašnje prilike, ali i odnosi sa susjedima, diktirali ritam napredovanja. Okvir koji je dao Proces stabilizacije i pridruživanja je u članu 9 Deklaracije iz Soluna izrazio očekivanje da države regiona prije svega prvo urede svoje međusobne odnose i izgrade mehanizme regionalne saradnje (European Commission, 2003), a onda pređu na viši stepen integracije, odnosno napreduju individualno.

Od te 2000. do danas jedino je Hrvatska uspjela sprovesti proces pristupanja do kraja. Zagreb je već 2003. podnio zahtjev za članstvo i nakon dvije godine priprema i sprovođenja potrebnih procedura, koje su u to vrijeme još naličile dotadašnjim procesima proširenja, 2005. uspio otvoriti pregovore (Schneider, 2009: 14). Pristupni 
pregovori su vođeni od 2005. do 2011, gotovo šest godina. Već u odnosu na prijašnja proširenja bilo je primjetno da se članstvo više ne može ispregovarati samo za dvije do tri godine, odnosno da se fokus sve više pomjera prema sagledavanju načina na koji države u praksi sprovode preuzetu pravnu tekovinu. Veliko pristupanje 2004. i kasniji ulazak Bugarske i Rumunije 2007. pokazali su da politika proširenja ne rješava sve probleme kandidata u pretpristupnom razdoblju i da u mnogim oblastima nove države članice jednostavno nijesu postigle ili održale nakratko uspostavljeni standard koji važi u starijim članicama Unije. Hrvatska je konačno pristupila EU 1. jula 2013, kao 28. država članica. Ovo je u istoriji evropskih proširenja bilo tek drugo individualno pristupanje Uniji, kao i posljednje prije uvođenja novog pristupa u pregovaranju.

Što se tiče ostalih država regiona, trenutno samo dvije države vode pristupne pregovore, Crna Gora i Srbija, dok su ostale u različitim fazama integracije.

Iako nezavisna tek godinu i po, Crna Gora je podnijela zahtjev za članstvo decembra 2008. pred sam kraj francuskog predsjedništva Savjetom EU kao prva od preostalih zemalja Zapadnog Balkana. Crna Gora je, tako, odmah nakon sticanja nezavisnosti jasno pokazala odlučnost da svoj državni prioritet ostvari kroz proces pristupanja i reformi koje će preduzeti. Ipak, ovaj zahtjev je karakterisala neizvjesnost stava Evropske unije. Države regije nijesu bile sigurne kako će proći zahtjevi i da li će se uopšte omogućiti započinjanje jednog novog vala zahtjeva s obzirom na to da se očekivalo da odmah nakon Crne Gore to urade i Albanija i Srbija. U periodu od decembra 2008. do aprila 2009. se čekala politička odluka o tome što uraditi s crnogorskim zahtjevom iako se radilo o automatskoj proceduri procesuiranja zahtjeva za članstvo iz Savjeta prema Komisiji. Nakon što je aprila 2009. postignut konsenzus, stvari su krenule prilično brzo. Crna Gora je dobila upitnik već u julu i odmah je krenula s izradom odgovora. Do kraja godine su i Albanija i Srbija podnijele zahtjev za članstvo, kako je i bilo očekivano. Crna Gora je kroz godinu dana, krajem 2010. dobila status kandidata. Preostalo joj je da ispuni još nekoliko, uglavnom političkih, kriterijuma prije nego što je decembra 2011. dobila zeleno svjetlo da krene s formiranjem pregovaračke strukture i pripremi državu za pregovore u poglavljima vladavine prava (23 i 24), a zatim u junu 2012. i zvanično započne pristupne pregovore s EU. Tokom pet godina vođenja pregovora otvoreno je 28 poglavlja, od kojih su tri privremeno zatvorena, a preostalih pet spremno je za otvaranje.

Pregovarački proces Crne Gore je po mnogo čemu specifičan. Prije svega, Crna Gora je prva država koja pristupne pregovore vodi po tzv. novom pristupu u čijem središtu su reforme u oblasti vladavine prava. Ovaj pristup je u djelo sproveo tadašnji komesar za proširenje i susjedsku politiku Štefan File. U svom govoru 2014. pred Evropskim parlamentom je predstavio novi paket proširenja: "2012. smo uveli prvi stub - novi pristup vladavini prava. Glavni elementi ovog novog pristupa 
su da se aspiranti za članstvo moraju izboriti s izazovima u poglavlju 23 Pravosuđe i temeljna prava i 24 Pravda, sloboda i bezbjednost u ranoj fazi procesa proširenja. Ojačali smo sistem mjerila i uveli tzv. klauzulu debalansa" (Govor komesara...). Kako je komesar i najavio, ovaj pristup će važiti za svako naredno otvaranje pregovora, što je u proširenom pristupu bilo vidljivo već kad je Srbija sljedeća otvorila pregovarački proces.

Srbija je decembra 2009. podnijela zahtjev i vrlo brzo dobila upitnik EU jer nije čekala političku odluku Savjeta, nego je išla po automatskoj proceduri na osnovu već postignutog dogovora za crnogorski zahtjev. Ova država je prošla isti put pripreme odgovora i nakon toga u martu 2012. dobila status kandidata, da bi do zvaničnog otvaranja pregovora došlo početkom 2014. Srbija je dosad otvorila 10 poglavlja, od kojih su 2 privremeno zatvorena. Pored novog pristupa u vladavini prava, Srbija je dobila i dodatno poglavlje kroz koje se mjeri napredak i balans između otvaranja i zatvaranja poglavlja u skladu s progresom koji se postigne kad su u pitanju poglavlja 23, 24, ali i 35. Ovo posljednje poglavlje, koje se, inače, obično ostavi za kraj pregovaračkog procesa za pitanja koja nijesu razriješena kroz uobičajena 33 poglavlja, je okvir za praćenje dijaloga koji Beograd vodi s Prištinom, odnosno očekivanje EU da stabilizacija odnosa i prevazilaženje međusobnih problema prati napredak u pregovorima drugih poglavlja. Ovaj dodatak za Srbiju znači da pored vladavine prava $u$ stalnom fokusu mora imati politički razvoj situacije $s$ Kosovom, dogovarati okvir za saradnju i sprovoditi postignute dogovore.

U slučaju Albanije koja je aprila 2009. podnijela zahtjev za članstvo, iako je praktički to uradila samo pet mjeseci poslije Crne Gore, dinamika nije bila slična. Prije svega, nakon dobijanja upitnika i odgovora koje je Tirana dostavila Briselu, prošlo je pet godina dok je juna 2014. dobila status kandidata. EU je ovoj državi ispostavila niz političkih uslova za dostizanje statusa kandidata, što je dodatno usporilo postizanje ovog rezultata. Kad je EK u novembru 2016. preporučila otvaranje pregovora s Albanijom, ova preporuka je i dalje bila uslovna. Obaveza sprovođenja pravosudnih reformi i prije svega provjere sudija je tako stavljena u primarni fokus uz očekivanje da izborni procesi proteknu u poštenoj atmosferi i bez kršenja zakona (European Commission, 2016). Preostaje, dakle, da Evropska komisija uradi novu procjenu na osnovu koje bi Savjet EU mogao donijeti odluku o daljim koracima, posebno u svjetlu narednog paketa proširenja na proljeće 2018.

Makedonski put prema članstvu u odnosu na prethodne četiri države predstavlja poseban slučaj. Riječ je o državi čiji je SSP stupio na snagu 2004. i koja je te iste godine podnijela zahtjev za članstvo, a već 2005. dobila status kandidata. U tim prvim godinama se činilo da će Makedonija imati uravnotežen i jasan proces pristupanja kakav je karakterisao prethodna proširenja, posebno imajući na umu da je bila prva država Zapadnog Balkana koja je zaključila ugovorni odnos s EU kroz 
svoj SSP. Ipak, posebnost makedonskog slučaja je činjenica da zbog neriješenih odnosa sa susjednom državom, koja je ujedno država članica EU, Skoplje ne može otpočeti pristupne pregovore i pored cijelog niza preporuka EK da se otvore pregovori s ovom državom još od 2009, uz činjenicu da godišnji izvještaji o napretku pokazuju usporavanje evropske agende i niži nivo spremnosti za članstvo (European Commission, 2016a) nego što bi se moglo očekivati od države koja je kandidat već 12 godina. Grčko-makedonski odnosi, odnosno spremnost da se nađe rješenje za pitanje imena su dobili nove mogućnosti nakon promjene vlasti i formiranja nove vlade u Skoplju maja 2017. Pitanje imena nije samo preduslov otpočinjanja pregovora za članstvo u EU, nego i za ulazak u NATO, i stoga je ovo prvorazredna politička stvar koju Makedonija mora razriješiti prije nego nastavi svoja dva integracijska puta.

Bosna i Hercegovina je, nakon niza godina izgubljenih na probleme interne prirode i nemogućnosti da SSP stupi na snagu uslijed pitanja prava drugih nacionalnih manjina pored tri konstitutivna naroda da se kandiduju i budu izabrani za člana Predsjedništva BiH, kao i za Dom naroda (tzv. Slučaj Sejdić-Finci), konačno podnijela zahtjev za članstvo u EU u februaru 2016. Ovome je prethodilo deblokiranje procesa na njemačko-britansku inicijativu krajem 2014. kad su ministri Hamond i Štajnmajer ${ }^{3}$ predložili da se Bosni i Hercegovini dozvoli dalji napredak pod uslovom da se nova vlada obaveže na reforme bez uslovljavanja slučajem SejdićFinci. ${ }^{4}$ SSP je tako stupio na snagu tek 1. juna 2015, iako je parafiran još 2007. U decembru 2016. BiH je dobila upitnik i u toku je priprema odgovora. Ipak, unutrašnje ustrojstvo i zaoštravanje političke situacije otežavaju kvalitet i efikasnost sprovođenja potrebnih reformi i predstavljaju problematičnu okolnost za napredovanje prema EU. Posebno je negativno odjeknula nedavna nemogućnost $\mathrm{BiH}$ da, uslijed unutrašnjih razlika i stava Republike Srpske, potpiše Ugovor o saobraćajnoj zajednici skupa s ostalim državama Zapadnog Balkana. Evropska komisija je najavila suspenziju fondova, a slovački ministar vanjskih poslova Miroslav Lajčak, nekadašnji visoki predstavnik za BiH, izrazio je sumnju da Bosna i Hercegovina uopšte može biti predložena za status kandidata $2018 .{ }^{5}$ Put integracije za ovu državu će zasigurno ostati još dugo bez pravog odgovora, odnosno dok se ne nađu rješenja za njezino interno uspješno funkcionisanje.

3 Dostupno na: http://www.auswaertiges-amt.de/EN/Infoservice/Presse/Reden/2014/141105BM_Aspen.html, 8. 8. 2017.

4 Dostupno na: https://www.reuters.com/article/us-bosnia-eu-accession-idUSKBN0IP1V62014 1105, 27. 7. 2017.

5 Dostupno na: http://balkans.aljazeera.net/vijesti/lajcak-bih-nece-biti-kandidat-za-eu-2018, 27. 7. 2017. 
Što se Kosova tiče, SSP je potpisan tek oktobra 2015, a stupio je na snagu 1. aprila 2016. Iako kasno potpisan u poređenju sa svima drugima, on je vrlo brzo ratifikovan i stupio na snagu zahvaljujući činjenici da nakon Lisabonskog ugovora Evropska unija ima pravo potpisati ugovore s trećim državama i nije potrebno da svaka država članica posebno potvrdi sporazum. Kosovo je tako prvo iskoristilo ovu mogućnost i izbjeglo problem da ga pet država članica EU (Grčka, Kipar, Španija, Rumunija i Slovačka) ne priznaje kao državu. Kosovo još nije ostvarilo ni viznu liberalizaciju i tako je jedino unutar granica zemalja EU koje i dalje mora posjedovati vizu za ulazak u države šengenske zone. Postavlja se pitanje što će biti ako Kosovo podnese zahtjev za članstvo, kako će pet država koje ga ne priznaju reagovati i da li će uopšte biti moguće procesuirati taj zahtjev kroz Savjet jednako kako je procesuiran i SSP. Naravno, dijalog Prištine s Beogradom će i za Kosovo ostati osnovni parametar napredovanja i bez pregovora kao okvira za odnose u novom pristupu.

\section{Izazovi pred državama članicama EU te kandidatima i potencijalnim kandidatima}

EU se suočila s mnogim izazovima tokom posljednjih godina, što je dovelo do toga da evropska politika proširenja izađe iz centra pažnje lidera Unije. Od njezinog uspostavljanja ova specifična institucionalna tvorevina prošla je kroz seriju transformacija koje nijesu promijenile suštinu mirovnog projekta bez presedana u skorijoj istoriji. Već dugi niz godina EU je atraktivan cilj za države centralne, istočne i jugoistočne Evrope kroz promovisanje zajedničkih evropskih vrijednosti demokratije, tolerancije i ekonomskog napretka. Politika proširenja Evropske unije je bila najvažnija pokretačka sila koja je omogućila kako njezino produbljivanje tako i jačanje tokom transformacijskih faza u njezinoj istoriji. Međutim, naročito u posljednjoj deceniji, Evropska unija se suočila s velikim brojem prvenstveno unutrašnjih, pa i eksternih kriza koje su šrom Evrope postepeno podsticale evroskepticizam i pokrenule preispitivanje identiteta EU i razloga njezinog postojanja. Teške posljedice ekonomske krize iz 2008. godine, specifičan geopolitički kontekst, uzdizanje populističkih partija, sve veće sigurnosne prijetnje, poseban odnos s Turskom, potencijalni izlazak Grčke iz EU, faktički izlazak Velike Britanije iz EU - sve ovo je podstaklo sumnje u kredibilnost $\mathrm{i}$ održivost evropskog projekta i učinilo da politika proširenja među evropskim donosiocima odluka zauzima sve niže mjesto na listi prioriteta.

Od devedesetih do danas države Zapadnog Balkana su prešle dug put u pogledu usklađenosti s evropskim standardima i vrijednostima, a članstvo u EU se pokazalo kao efikasan mehanizam za podsticanje ukupnih reformi. Međutim, okrenutost Unije rješavanju vlastitih problema i marginalizacija politike proširenja či- 
ne da političke elite gube ritam i energiju, a smanjeno prisustvo EU u regionu pojačava uticaj trećih država i ostavlja prostor za smanjenje povjerenja građana $u$ evropski projekt. Posljednja dešavanja i porast tenzija i nestabilnosti u državama regiona upravo to potvrđuju. Ubrzanje procesa bi intenziviralo dalju demokratizaciju i transformaciju država regiona, dok bi njegovo usporavanje ili stopiranje imalo negativne posljedice ne samo za region nego i za EU. Zato je važno da Evropa bude prisutnija na Zapadnom Balkanu i nastavi s aktivnom podrškom integraciji regiona ne samo u političkom, ekonomskom i administrativnom nego i kulturnom, odnosno vrijednosnom smislu. Nekadašnje živo prisustvo i interesovanje međunarodne zajednice tokom prve decenije novog milenijuma je zamijenilo odsustvo $\mathrm{i}$ zaokupljenost evropskih glavnih gradova drugim kriznim regionima i novim unutrašnjim problemima (Jović, 2015). Berlinski proces jeste na neki način zamijenio nedostatak sastanaka na vrhu i doveo Zapadni Balkan u fokus važnih država članica EU, ali nije uspio postati platforma za političke odluke u regiji ili korisni kanal komunikacije za rješavanje problema (Fouéré i Blockmans, 2017). Evropska unija i dalje nema odlučan odgovor na pitanje kad bi se proces pristupanja preostalih država Zapadnog Balkana mogao završiti, ali ni pravi odgovor na pojačanu aktivnost trećih aktera u slučaju njihove veće zainteresovanosti da postanu bitniji igrači na Balkanu (Reljić, 2016).

Prvi ozbiljan udarac slici Evropske unije kao primjera uspjeha i prosperiteta došao je s prvom ekonomskom krizom koja je pogodila Evropsku uniju 2008. i ostavila ožiljke koji traju i danas, gotovo cijelu deceniju poslije. Uslijed dugotrajne dužničke krize, bankovnih krahova i nedostatka rasta, ekonomska i monetarna unija je pokazala niz grešaka i slabosti. Čak i pored toga što je odgovor na to bilo uspostavljanje bankovne unije i pojačan makroekonomski nadzor kako bi bilo osigurano da članice poštuju fiskalna pravila, a njihov dug bio smanjen, ove mjere su pojedine države članice gurnule u poteškoće i čak dovele države izvan eurozone u donekle nepovoljan položaj, odnosno u rizik da budu istisnute iz glavnih tokova odlučivanja. Kada je riječ o državama kandidatima, tokom posljednjih godina postalo je sve teže ispuniti ekonomske kriterijume. Fokus je prebačen na ekonomsko upravljanje jer su kandidati i potencijalni kandidati praktično pozvani da slijede pravila evropskog semestra ${ }^{6}$ čak i prije nego što postanu članice EU. Ovo je urađeno u drugoj generaciji tzv. novog pristupa, tako što su svi kandidati i potencijalni kandidati obavezani da usvoje programe ekonomskih reformi i da prate zahtjeve Unije. Nakon što ih predstave Evropskoj komisiji i Savjetu, ministri finansija i ekonomije EU donose zaključke i preporuke kojima instruiraju aspirante u kojem smjeru treba da

${ }^{6}$ Evropski semestar je ciklus šestomjesečne koordinacije ekonomske i monetarne politike EU tokom kojeg se zajednički koordinira budžet, politika zapošljavanja, ekonomija i druge srodne oblasti. 
razvijaju svoju ekonomsko-monetarnu politiku, ali i šire reforme na polju prosvjete, zapošljavanja i drugog.

Entuzijazam za širenje EU umnogome je smanjen s posljednjim velikim valom proširenja 2004. Upravo nakon ovog posljednjeg prikaza posvećenosti jedinstvenoj Evropi na cijelom kontinentu i, paradoksalno, uza sve izuzetno pozitivne indikatore koji pokazuju cijeli niz koristi koje je proširenje donijelo i starijim i novim članicama, pojam "zamor od proširenja" ulazi u politički život Evrope. Velika Evropska unija gdje 28 predstavnika sjedi za jednim stolom i gdje je potrebno nekoliko sati da svaki govornik uzme riječ i za nekoliko minuta predstavi svoj stav je zasigurno značajno drukčija od prošlih unija u kojima se dogovor postizao među članicama koje slično razmišljaju, imaju iste ekonomske ciljeve i zajedničkog neprijatelja u Hladnom ratu. Današnja Unija je za elite mnogih starijih članica previše glomazna i daleko od onoga čemu su osnivači projekta težili.

Ono što danas predstavlja poseban izazov za budućnost proširenja ipak nije puka glomaznost i brojnost u Uniji. Mnogi na Zapadu smatraju da nove države članice nijesu uspjele dokazati svoju sposobnost da dijele zajedničke vrijednosti s ostatkom EU, uključujući puno sprovođenje vladavine prava. Odnosi koji postoje s Mađarskom i Poljskom, stalno pozivanje na kršenje fundamentalnih pravila vladavine prava, odnos prema migrantima, pravosudni sistem, sve je to okrnjilo zajedništvo unutar EU, ali i dovelo do razmišljanja da proširenje nije uspjelo promijeniti nove članice do te mjere da se ponašaju i funkcionišu kao stare države Evrope. Dodatna posljedica je stroži skup političkih kriterijuma za države kandidate, što je na primjer prouzrokovalo novi pristup Evropske komisije u ocjenjivanju poglavlja $23 \mathrm{i}$ 24 za Crnu Goru 2012. S druge strane, javnost širom Evrope je postajala sve nepopustljivija i rezervisanija jer su građani EU izgubili vjeru u sposobnost EU da riješi njihove probleme i brige. Najjasniji izraz ove politike se vidio u izjavi predsjednika Evropske komisije Žan-Kloda Junkera koji je "predložio da se zakoči" s proširenjem (Solioz, 2014). Junkerovu izjavu treba prije svega shvatiti u kontekstu unutrašnje politike EU, odnosno elektorata koji, kao što je ranije predstavljeno, nikako nije oduševljen politikom proširenja. Pored toga, rast partija ekstremne desnice, koje podržavaju evroskeptični populizam i na Zapadu i na Istoku Evrope doveo je do toga da tradicionalne partije sve više preuzimaju politike ekstremnih stranaka. ${ }^{7}$ Kao posljedica toga, na izborima za Evropski parlament održanim 2014. zabilježena je najniža izlaznost $u$ istoriji. Sve to je podstaklo atmosferu zamora od proširenja na obje strane - među državama članicama i aspirantima. Najnovija izjava komesara

${ }^{7}$ Usp. situaciju u Holandiji, gdje partije centra u velikom dijelu preuzimaju politiku strožeg odnosa prema migracijama vođene upravo popularnošću ovih politika u elektoratu (Economist, dostupno na: https://www.economist.com/news/europe/21723867-three-months-after-electionpopulists-appear-not-have-lost-badly-everyone, 1. 8. 2017). 
za susjedsku politiku i pregovore o proširenju Johanesa Hana da nije isključeno da će u periodu narednog Evropskog parlamenta i Evropske komisije doći do proširenja ${ }^{8}$ može biti protumačena kao otpimistički pogled na period 2019-2024, ali jednako tako i kao davanje obećanja za ono što ne spada u mandat aktuelnih institucija.

Izbjeglička kriza koja je 2015. pogodila evropsko tlo stavila je brojne nove izazove pred EU. Fenomeni sigurnosti i migracija su se stopili u težak zadatak za rješavanje pred šefovima država ili vlada EU. Tek je 2017. donijela olakšanje kad je u pitanju priliv migranata i zahtjeva za azil, koji su prepolovljeni. ${ }^{9}$ Osim što kreira načelnu zabrinutost za efikasnu integraciju imigranata, ova značajna migracija koja je Evropi donijela milione ljudi koji traže azil, sigurnost i bolji život, ide paralelno s veoma ozbiljnim sigurnosnim pitanjima, odnosno terorizmom. Izbjeglička kriza je pokazala još jednom manjak povezanosti politika EU. Jedinstva među članicama nestalo je kada je EU kvalifikovanom većinom odobrila obavezni plan realokacije podnosilaca zahtjeva za azil iz Grčke i Italije u septembru 2015. jer su određene države Centralne Evrope glasale protiv. Evropska komisija i dalje razmatra na koji način može pokrenuti procedure kršenja pravila, odnosno pravne tekovine EU u ovoj oblasti i na taj način uticati na nevoljne države članice. Nedavno mišljenje generalnog advokata Evropskog suda pravde Iva Bota u kojem predlaže da se odbace žalbe Mađarske i Slovačke po pitanju programa realokacije migranata EK (Court of Justice of the EU, 2017) će svakako imati uticaja na političko djelovanje u narednim mjesecima. S druge strane, pojedine države kandidati su bile suočene s posebnim izazovom jer migranti koji dolaze u Grčku koriste takozvanu zapadno-balkansku rutu, prolazeći kroz Makedoniju i Srbiju u Mađarsku i Hrvatsku, a zatim prema zapadnoj Evropi. Ovo je države Zapadnog Balkana stavilo u centar pažnje EU, posebno imajući na umu činjenicu da su migranti izlazili iz šengenske zone (Grčka), prolazili kroz države proširenja, da bi onda opet pokušali ući u države šengenske oblasti. Ovo je pokazalo sve propuste i nespremnost eksternih granica i sistema nadzora kretanja migranata, kao i potrebu da se radi na novoj pravnoj tekovini i sistemu upravljanja kretanjem ljudi.

Niz potencijalnih i stvarnih "izlazaka", od "greksita" do "breksita", iznio je na vidjelo ozbiljnu krizu identiteta EU i doveo u pitanje opravdane osnove za njezino postojanje kada je riječ o sposobnosti da zastupa i štiti interese svih evropskih građana. Iako na kraju nije došlo do stvarnog izlaska Grčke, ni iz EU, a ni eurozone, pošto je 2015. Grčka prihvatila sporazum Komisije i povjerilaca kojim se sprovode veće mjere štednje i strože ekonomske reforme kako bi ostala u njoj, ipak su se otvorila brojna pitanja povezana sa samom strukturom i održivosti pomenute zone.

${ }^{8}$ Dostupno na: https://issuu.com/dnevne-novine/docs/787156_4_1497321245, 16. 8. 2017.

9 Dostupno na: http://ec.europa.eu/eurostat/statistics-explained/index.php/Asylum_quarterly_ report, 16. 8. 2017. 
Jednako tako je podijelila države članice oko toga što je važnije za stabilniju eurozonu - tješnja politička integracija, što je podržala Francuska, ili stroža fiskalna pravila, kako to vidi Njemačka. S druge strane, Britanci su se opredijelili za izlazak iz EU na referendumu održanom u junu 2016, što je izazvalo polemiku o budućnosti EU. Do kraja marta 2019. Britanija mora završiti bolan proces razdruživanja, a Evropska unija pronaći novi način da zadrži ideale ujedinjenja i jedinstva unutar zajednice. Aspiranti za članstvo vrlo pažljivo posmatraju razvoj situacije u ovim novim okolnostima, naročito kad svojoj javnosti predočavaju pozitivne strane članstva u EU. Iako je suština pristupnih pregovora sada, i uvijek će biti, stalan rad na samounapređenju država kandidata u pogledu reformi, bolje vladavine prava, ekonomskog upravljanja i jačanja institucija, javnost treba da bude i objektivno informisana o svim trenutnim izazovima s kojima se suočava EU, uključujući pitanje identiteta i budućnosti EU. Prvi put nakon 60 godina se više ne može govoriti o ireverzibilnom procesu ujedinjenja evropskog kontinenta.

\section{EU i uticaj trećih aktera na Zapadni Balkan}

Geopolitičke okolnosti, koje se prvenstveno odnose na rast evroskepticizma u EU, izlazak Velike Britanije iz EU, migracijsku krizu, sankcije EU prema Rusiji i razna druga dešavanja nalaze snažno uporište u svakodnevnom političkom životu država Zapadnog Balkana i otvaraju dodatan prostor za nove aktere u regionu. Period brojnih parlamentarnih izbora u regionu, praćenih vatrenim i nacionalističkim retorikama na svim stranama, dokazao je osjetljivost ovog područja te koliko je malo potrebno za izazivanje nestabilnosti. U svjetlu predizbornih i postizbornih procesa, u posljednje vrijeme se više nego ikad osjeća uticaj trećih zemalja, kao i antievropska ili antinatovska retorika. Takođe, produbljivanje odnosa i prisnost s Rusijom, odnosno tradicionalno rusko prijateljstvo prema slovenskim zemljama je naročito vidljivo u državama kod kojih je u jednom dijelu političkih partija, iz prostog interesa, prisutna velika simpatija prema proruskom uticaju kao onom koje ih ili može dovesti na vlast ili sačuvati od gubitka vlasti. Nesporno je da je i pad podrške evropskoj integraciji (Minić, 2015: 25) iskorišten kako bi se predstavile druge alternative: tradicionalni pravoslavni prijatelji, manje fokusa na vladavinu prava i pravila tržišne ekonomije, manje strogih standarda u ljudskim pravima, drugim riječima sve ono što predstavlja najteži i najzahtjevniji dio evropskog reformskog procesa. Imajući u vidu da ovaj uticaj ne postoji niti može uhvatiti korijena u Albaniji i na Kosovu zbog znanih istorijskih, ali i aktuelnih okolnosti, poseban akcent se stavlja na Srbiju, Crnu Goru, Bosnu i Hercegovinu (odnosno Republiku Srpsku) i Makedoniju.

Razvoj ovog posebnog geopolitičkog ambijenta je dostigao kulminaciju s krizom u Ukrajini početkom 2014. Naime, on je dodatno uzdrmao čvrste temelje evropskog projekta sagrađenog na vrijednostima mira, demokratije, tolerancije i ljudskih 
prava. Pripajanje Krima i intervencija u istočnoj Ukrajini su istaknuli sporu reakciju i nedostatak jedinstva u strukturama odlučivanja Evropske unije. Uprkos činjenici da Evropska unija sprovodi restriktivne mjere prema Rusiji, neke države članice bile su nevoljne da ih na dosljedan način i u punoj mjeri slijede. Ovo može biti posmatrano kao još jedan indikator nemogućnosti EU da govori jednim glasom prema drugim geopolitičkim akterima. Zajedničku politiku u ovoj oblasti nijesu, pak, slijedile ni sve države kandidati, pa tako Srbija, Turska i Makedonija, kao i potencijalni kandidat Bosna i Hercegovina, odbijaju da se u potpunosti priključe ovom jedinstvenom stavu EU prema Rusiji (Perkučin i Novaković, 2017).

Crna Gora je još 2014. donijela čvrstu političku odluku da ne odustaje od svog evro-atlanskog puta i pored viševjekovnih prisnih istorijskih, političkih i kulturnih veza s Rusijom i u potpunosti je primijenila restriktivne mjere Evropske unije kao stvar principa. S druge strane, Rusija je odlučna u namjeri da ne samo očuva nego i ojača svoj uticaj na Balkanu. Upravo je u Crnoj Gori Rusija kroz razne mehanizme (trgovinske, svoje restriktivne mjere, medijske kampanje) i posrednike (političke partije, nevladine organizacije, ali i crkvu) povećala svoj pritisak kako bi iskazala nezadovoljstvo što je jedna balkanska država koja nije u EU uvela restriktivne mjere prema ruskim državljanima. Iako, možda više od svih ostalih država, ima najdublje istorijske korijene s Rusijom, s kojom je 2011. proslavila 300 godina od uspostavljanja diplomatskih odnosa, Crna Gora je od obnove nezavisnosti 2006. jasno naglasila svoj vanjskopolitički kurs - članstvo u EU i NATO-u. Kao rezultat ovog cilja, Crna Gora se od najnerazvijenije republike u SFRJ pozicionirala kao predvodnik evropske integracije i kao država koja je na samom pragu ulaska u NATO, s najvećim BDP-om po glavi stanovnika u regionu Zapadni Balkan. Međutim, snažna antinatovska kampanja jednog dijela opozicije, uz evidentnu podršku iz Rusije, koja se pojačavala u skladu s približavanjem Crne Gore članstvu u Alijansi, bitno je uzdrmala ondašnju političku scenu u Crnoj Gori, koja je uživala priličnu stabilnost političkog sistema u poređenju s ostatkom regije. Ulaskom u NATO početkom juna 2017. se čini da je stavljena tačka na pitanje stabilnosti i budućnosti ove države u okviru transatlantskog sigurnosnog okvira, no ostaje za vidjeti kako će se stvari razvijati u narednom periodu ne samo u Crnoj Gori nego i u ostatku regiona.

Pitanje uključenosti Turske na Zapadnom Balkanu svakako nije bilo u fokusu poput pitanja uključenosti Rusije. Turska je, prije svega zahvaljujući činjenici da nije imala razrađenu i temeljitu vanjsku politiku prema Balkanu prije pada Berlinskog zida, kasno ušla na Balkan i krenula s promocijom svojih interesa. Ipak, ovaj uticaj je u ekonomskom i religioznom smislu dobio na snazi posljednjih deset godina. Kako je rasla moć trenutno vladajuće turske partije AKP, tako su rasle i investicije, aktivnosti agencije za razvojnu pomoć Tika, ali i politički uticaj. Ahmet Davutoglu je to objasnio u svojoj knjizi Strategijska dubina, u kojoj navodi potrebu novih eleme- 
nata turske vanjske politike prema svojim susjednim zemljama i regionima, pa tako i Balkanu, odnosno činjenicu da "turski susjedi na Balkanu, Bliskom istoku, Kavkazu i Centralnoj Aziji očekuju vođstvo od Turske" (Govor Ahmeta Davutoglua...: 9). Ovaj politički uspon je pratio i kulturni i obrazovni kroz niz univerziteta i obrazovnih ustanova koje su turska država ili privatne organizacije otvorile posljednjih godina širom Zapadnog Balkana. Raskol između zvanične Turske, odnosno AKP, i Fetulaha Gulena je usporio ovaj val novih školskih ustanova te doveo i do političkih sukoba u kojima je Ankara otvoreno tražila od vlada na Zapadnom Balkanu da zatvore Gulenove institucije.

Za razliku od ruskog uticaja koji je dominantan upravo u državama s većinski pravoslavnim stanovništvom, Turska je primarno usmjerena na Albaniju i Kosovo i bošnjački dio Bosne i Hercegovine. Istorijske, kulturne, sve jače ekonomske i političke veze karakteriše primjetno nastojanje Ankare da bude faktor na Balkanu i ponudi alternativne mogućnosti za saradnju i sagledavanje budućnosti ovih zemalja. Naporedo s ovim procesom, tursko odmicanje od evropske integracije je unijelo i novi element $\mathrm{u}$ odnosima. Ranije, dok je cilj članstva u EU bio nepodijeljen između balkanskih država i Turske, razmatranje zajedničke budućnosti je razumljivo bilo uokvireno evropskom integracijom. Ipak, danas govorimo ne samo o različitoj dinamici pristupanja između regiona Zapadnog Balkana i Turske nego i o sve većoj razlici u političkom gledanju na budućnost i posvećenost ulasku u EU.

Radikalizam i ekstremizam su, takođe, sve prisutniji kao fenomen na Zapadnom Balkanu. Hanafi islam koji je ostao dominantan na Balkanu nakon raspada Osmanskog Carstva danas je suočen s novim uticajima vehabizma i salafizma (Elbasani i Roy, 2015). Tokom etničkih konflikata devedesetih, a i kasnijim sve aktivnijim djelovanjem nekih muslimanskih država i finansiranjem izgradnje novih bogomolja i vjerskih centara, došlo je do rasta uticaja drugih pogleda na to koji islam se treba ispovijedati na Balkanu. U mnogim balkanskim državama tako postoji niz džamija i džemata koji nijesu pod kontrolom službenih islamskih zajednica, što se posebno primjećuje u Bosni i Hercegovini i u Albaniji (Bogdani et al., 2016). Kroz ove centre se najčešće regrutuju i strani ratnici za učešće na ratištima u Siriji i Iraku. $\mathrm{Na}$ stotine ljudi s Balkana je otišlo na ratišta na organizovan ili individualan način. Džejms Kenet Vider pominje 700 ratnika s Balkana na ratištima u Siriji, najviše s Kosova, iz Bosne i Hercegovine i Albanije (Wither, 2015). Dešavanja u Kumanovu maja 2015. su kod svih balkanskih zemalja izazvala potrebu da se sagleda ova nova prijetnja i uticaji koje ekstremisti mogu imati po stabilnost regiona (Bogdanovski, 2015). Nakon Kumanova, gotovo sve države Zapadnog Balkana su izmijenile svoje zakonodavstvo kako bi kriminalizovale učešće na stranim ratištima, i nastupio je period unaprijeđene saradnje na ovom polju. Određeni dio balkanskih boraca na bliskoistočnim ratištima je u međuvremenu poginuo, dio je ostao u državama destina- 
cije, a dio se vratio u svoje države, gdje se morao suočiti s činjenicom da je njihovo učešće u ratovanju stavljeno izvan zakona.

Sve ove mjere govore kako se region polako adaptirao na novonastale okolnosti, iako je svaka država imala svoj pristup. Ipak, to ne znači da je opasnost po stabilnost budućih odnosa na Zapadnom Balkanu prestala. Ekstremizam koji je izašao iz boce krajem osamdesetih je samo unaprijeđen i nadopunjen novim dimenzijama. Danas više ne govorimo samo o lokalnim dometima i vezama ekstremista, nego o cijeloj mreži koja je postala izuzetno aktivna na internetu. Preko 60 sajtova $^{10}$ na Zapadnom Balkanu promoviše radikalne ideje i ekstremizam i njihovo djelovanje se ne može zanemariti. Evropska unija, s druge strane, treba da iznađe mehanizme kako da se suoči s uticajima trećih strana. Neki autori se zalažu i za olakšavanje kriterijuma za članstvo u kontekstu sve izraženijeg prisustva trećih strana na Zapadnom Balkanu (Bechev, 2015). Opasnost od novog sukoba podstaknutog uticajima trećih strana i korištenja Balkana za ostvarivanje geopolitičkih ciljeva u drugim regionima svijeta, kao i svježe sjećanje na konflikte iz devedesetih godina prošloga vijeka ostavljaju dosta prostora za razmišljanje o tome da li Evropska unija, NATO, pa i SAD treba da budu aktivniji i prisutniji na Balkanu.

\section{Zaključna razmatranja - mogući scenariji varijabilne realnosti Zapadnog Balkana}

Ako bi se kroz jedan izraz mogao sažeti proces priključenja zemalja Zapadnog Balkana Evropskoj uniji u kontekstu sadašnjih mogućnosti i izazova, onda je možda prikladan izraz heterotemporalnosti (Lopandić, 2017) kao stanja u kojem vremenski ciklusi i mandati nisu usklađeni unutar Evropske unije, ali ni u odnosu Evropske unije i Zapadnog Balkana. Njemu bi se svakako mogao dodati i onaj varijabilne realnosti u kojoj usitnjeni Balkan živi uporedo u nizu stvarnosti, gdje svaka ima svoj ishod i konsekvence. Različiti vremenski okviri i različite realnosti su stvarnost država regiona. Kako u toj arhitekturi pronaći najbolji način da se iskoristi vrijeme pristupanja EU, uz što bolje planiranje, strategijsko postavljanje i što bolje vizije eventualnog datuma ulaska u članstvo? Međutim, je li ideja evropeizacije zaista tako snažno ukorijenjena na Zapadnom Balkanu, odnosno na Balkanu uopšte? Je li zaista članstvo u EU tako privlačno za sve, gubi li na atraktivnosti, i konačno razumiju li to u Briselu (Subotić, 2011: 313)? Ako pođemo od presumpcije da je privlačnost članstva, odnosno evropeizacije i dalje nadmoćna u odnosu na sile koje vuku prema drugim alternativama, na Istok, moglo bi se reći, onda moramo postaviti i pitanje koliko dugo će ova ideja ostati ovako privlačna. Uz nabrojene sve teškoće

${ }^{10}$ Dostupno na: http://www.balkaninsight.com/en/article/far-right-balkan-groups-flourish-onthe-net-05-03-2017, 21. 8. 2017. 
i sve manji entuzijazam članica EU, teško je procijeniti da li ideja članstva ostaje i dalje primamljiva. U nastavku se daje pregled četiri moguća scenarija za Zapadni Balkan uz mogućnosti odstupanja u skladu sa smjerom kretanja različitih dijelova sistema koji čine cio proces visoko podložnim nizu mogućnosti. Ipak, glavne smjernice i strukture mogućeg razvoja situacije se mogu odrediti u načelu i ovdje se mogu posložiti na ovaj način:

1. Postepeni ulazak svake od zemalja ponaosob kao scenario koji figurira kao zvanična politika Evropske unije, ali i u stavovima država regiona. Za očekivati je da ovaj proces potraje dugo, možemo govoriti o deceniji do više decenija. U njemu možemo zamisliti da Crna Gora nastavi ovim ritmom kojim je i krenula te, sad nakon što je ušla u NATO, u nekoliko narednih godina i završi pregovore kako bi za mandata naredne Komisije i Evropskog parlamenta postala članica. Odmah iza nje bi mogla slijediti Srbija koja bi narednih godina uspjela riješiti svoje strukturne probleme i probleme odnosa s Prištinom. Albanija će, moguće, sredinom 2018. otvoriti pregovarački proces, tako da bi se i ona mogla kandidovati za pristup EU u narednih deset godina. Za Makedoniju mnogo toga će zavisiti od načina na koji uspije sačuvati internu stabilnost, kao i da riješi pitanje imena sa svojim susjedom, nakon čega bi tehnički mogla ubrzati pristup i Alijansi i Uniji. Bosnu i Hercegovinu i Kosovo, svaku iz svog razloga, s druge strane, očekuje dug put i dosta neizvjesnosti do postizanja stanja u kojem će biti završen integrativni put. U najboljem slučaju se mogu nadati članstvu tek u drugoj deceniji ako se za to stvore uslovi u narednim godinama. Ovakav pristup podrazumijeva da stanje u regionu ostane stabilno, da se EU razvija bez turbulencija istovremeno snažeći svoje pozicije i pronalazeći volje i snage da završi procese proširenja, kao i da treći akteri ne ugroze proces većim angažmanom. Istovremeno, ovaj scenario je podložan individualnom razvoju situacije u svakoj od država proširenja, ali i u samim državama članicama EU, gdje je lako zamisliti da bilo koje buduće proširenje bude odbačeno na eventualnom referendumu.

2. Upravo polazeći od ovih problema s kojima se susreću države članice u želji, ali i sve češće u nedostatku volje i želje da sprovedu politiku proširenja, možemo zamisliti drugi scenario u kojem je evolucija, odnosno mutacija politike proširenja (Wallden, 2017: 10) zaista ušla u fazu u kojoj se otvoreni proces bez datuma i bez posvećenosti može pretvoriti u stalno odugovlačenje bez namjere da Unija poveća broj svojih članica u dogledno vrijeme. Evropa više brzina, koja izaziva niz teorija o tome da će upravo ovaj koncept ozvaničiti kraj jedinstvene Unije, pruža plodno tlo da se razmišlja o tome koja je brzina sačuvana za Zapadni Balkan i Tursku u ovom scenariju. Je li to stanje ekonomske, carinske i trgovinske povezanosti s Evropskom unijom, ali i stanje nikad ostvarenog članstva? Takva 
Evropska unija na više nivoa i s različitim brzinama koje bi zadovoljile različite potrebe raslojenih interesa država članica EU bi lakše mogla ponuditi mehanizam saradnje s neželjenim novim članicama, riješila bi prvenstveno problem turskog članstva, možda pronašla i rješenje za Veliku Britaniju i njezin odnos s Unijom, a Zapadni Balkan bi među ovim velikim igračima dobio neko svoje mjesto, ali ne i članstvo. Napokon, čak i bez konteksta varijabilne geometrije Evrope, već započete promjene u politici proširenja se mogu posmatrati kao takve da ne daju osnova za optimizam da će se proces primanja u članstvo novih država izgledno desiti. Evolucija politike proširenja u kojoj nikad zaista nema novog proširenja bi svakako bio poguban scenario za Zapadni Balkan, ali bi za mnoge unutar EU bio idealno rješenje zbog manjka entuzijazma za nove članice, bez obzira na to što prekid proširenja niti može riješiti probleme Unije, niti je uzrok kriza i poteškoća koje su snašle Uniju.

3. Treći scenario podrazumijeva potrebu da se iznađe grupno rješenje za Zapadni Balkan, jedna vrsta nove solunske agende s jasnim kalendarom koja bi na bolji i kvalitetniji način riješila pitanje stabilnosti i integracije ovog regiona. Ovo podrazumijeva jaku i stabilnu Uniju koja radi skupa s NATO-om. Kako kažu Račev i Slavkova: "ako je EU nesposobna da Zapadni Balkan učini svojim prioritetom, onda NATO tek ima mnogo manje šanse da bude snažan faktor transformacije" (Ratchev i Slavkova, 2017: 4). Samo tako, i uz razumijevanje Vašingtona, mogao bi se napraviti novi dogovor, novo rješenje za Zapadni Balkan, koje bi podrazumijevalo jedan novi i kreativniji pristup, pri čemu će politički i geostrategijski kriterijumi biti mnogo važniji od tehničkih. Bilo bi neophodno da se dogovore jasni i razumljivi zahtjevi i obaveze za zemlje regiona uz koje bi se dobio i konkretan vremenski raspored za završetak procesa integracije. Pri tome bi političko odlučivanje vodilo i povlačilo za sobom reforme i završetak posla na prilagođavanju evropskim standardima, ali bi politički pritisak i nova dinamika omogućili brže pristupanje i rješenje za cio region. Ovim se, naravno, ne bi pravile prečice i rješenja nauštrb onoga što države zaista moraju uraditi kako bi postale članice EU i NATO, ali bi zato dobili jednu novu energiju i mogućnost da se integracija na Zapadnom Balkanu završi u skorije vrijeme uz preko potrebnu stabilizaciju i ekonomski napredak. Upravo smo vidjeli EU na djelu tokom migrantske krize kad su geopolitički razlozi bili primarni u odnosu na tehničke u dogovoru s Turskom. Unija je dobila predah u tokovima migranata, ali je i izgubila principe u svojoj politici uslovljavanja. U vrijeme kriza i opasnosti, politički dogovori obično odnesu pobjedu nad uobičajenim ili tehničkim pristupom i potrebno je razmišljati i djelovati kreativno i uz sagledavanje šire slike. Ovo može biti šansa za politiku proširenja koja može dobiti novi zamah i donijeti rješenje ne samo Balkanu nego i Evropi. 
4. Konačno, rizični i katastrofični scenariji su najmanje izgledni, ali ipak uvijek mogući, posebno kad govorimo o prostorima Jugoistočne Evrope i vremenu u kojem se dešavaju velike promjene na geopolitičkoj sceni. Izjava Žan-Kloda Junkera, koji je najavio da za njegove komisije neće biti proširenja i da, ako Zapadni Balkan izgubi evropsku perspektivu, "opet ćemo iskusiti ono što smo doživjeli devedesetih" 11 mogla bi se ostvariti. Činjenica da mnogi ne uzimaju za ozbiljno opasnosti i ono s čime se regioni u Jugoistočnoj Evropi, Mediteranu i dalje na istoku suočavaju, može jednostavno dovesti do razvoja situacije u kojoj će stvari krenuti reverzibilnim tokom. Moguće je zamisliti razne scenarije u kojima Turska prekida pregovore o članstvu, Evropska unija zaustavlja pregovarački proces na određeno vrijeme, treba zamisliti i novi sastav Evropskog parlamenta i raspoloženje u njemu prema novim članicama; moguće je zamisliti i dalje kvarenje odnosa između Brisela i Poljske i Mađarske, koji vode takvom sukobu da Unija i ne želi otvoriti nova pristupanja. Pored toga, migrantska kriza je možda samo nakratko posustala, moguće je da će pritisak iz Azije i Afrike sve više rasti i da će se i Zapadni Balkan naći pred značajnim problemima. Radikalizacija i ekstremizam mogu doseći razmjere zbog kojih će biti nemoguće stabilizovati regiju jer oni nijesu izolovani balkanski fenomen, nego su duboko povezani s drugim dešavanjima i regijama pod uticajem ekstremista (Hide, 2014: 379), a možemo zamisliti i na koji način bi treće strane mogle ostvariti značajne dobitke sve krhkijim stanjem na Balkanu. I Evropska unija i NATO su društvene tvorevine i samim tim podložne promjenama u društvu i izazovima uslijed kojih se mogu promijeniti, ali i nestati sa svjetske scene, kako je to bio slučaj s nizom država, imperija i drugih državnih tvorevina kroz ljudsku istoriju. Stoga, nikako ne treba zanemariti ili podcijeniti mogućnosti destabilizacije, haosa i novih konflikata na Balkanu, koji bi u ovakvoj konstelaciji odnosa i stanja na evropskom kontinentu, ako dosegnu kritičnu masu, zadali krajnji udarac šansama za dalju integraciju.

Kroz ova četiri scenarija, koji mogu biti parcijalno, ali i dobrim dijelom tačni, najbolje se vidi koliko je budućnost proširenja na Zapadnom Balkanu, u stvari, neizvjesna. Postoje mnoge formule, mnogobrojne mogućnosti i velike šanse uz značajne uslove koji se moraju ispuniti. Pred regionom je budućnost koja će umnogome zavisiti od dešavanja unutar samih zemalja regiona, njezinih susjeda, same Evropske unije, ali i razvoja situacije u regionima koji okružuju Evropu. Nakon Samita šefova država ili vlada u martu 2017. u Rimu, predstavljeni koncept Evrope više brzina je nepoznanica i razlog za duboko razmišljanje i sagledavanje svoje pozicije ne samo za države članice EU nego i za države proširenja. Kakvo mjesto će

11 Dostupno na: https:/europeanwesternbalkans.com/2017/08/03/juncker-stability-prerequisitebalkans-not-war/, 17. 8. 2017. 
imati i čemu će se države proširenja priključiti narednih godina, koja će to brzina biti određena za nove članice i kako će EU izgledati jednom kad se proces proširenja na Balkanu završi? Sve su to različite stvarnosti, ali i pitanja na koja malo ko danas ima odgovora, a ključna su za određivanje budućnosti cijelog kontinenta.

Varijabilna realnost Zapadnog Balkana može biti dio varijabilne geometrije Evropske unije na nekoliko načina, kako ovaj rad i pokušava pokazati kroz moguće scenarije, donoseći pozitivne ili negativne konsekvence ne samo po region nego i šire. Politika proširenja je proteklih više od pedeset godina bila stub stabilnosti za Evropsku uniju, ono što je na najbolji način prikazivalo privlačnu moć i kvalitet koji Unija donosi cijelom kontinentu, ali i svijetu. Danas politika proširenja nije više instrument kojim se pokazuje moć transformacije ili snaga Unije, ona je politika koja se oslanja na stara obećanja i potrebu da se sačuva mir na kontinentu, podložna stavovima javnosti i često korištena da se objasne problemi za koje su krivi potpuno drugi uzroci. Vizija koja nedostaje samoj Evropskoj uniji nedostaje i ovoj politici i pitanje je kojim putem će Balkan nastaviti svoj put. Zato je neophodno dodatno i iznova promišljati sve uslove i sve reperkusije ovog procesa kako bismo izbjegli ponavljanje ranijih sukoba, zaostajanja i pokrenuli regiju prema boljoj budućnosti.

\section{LITERATURA}

Adebahr, Cornelius i Töglhofer, Theresia. 2015. Germany - EU Member States and Enlargement towards the Western Balkans. European Policy Centre. Brussels.

Bechev, Dimitar. 2015. Russia in the Balkans: How should the EU respond?, EPC Policy Brief. EPC. Brussels.

Bogdani, Aleksandar et al. 2016. Balkan Jihadists, The Radicalisation and Recruitment of Fighters in Syria and Iraq. BIRN. Beograd.

Bogdanovski, Andreja. 2015. Fighting violent extremism in the Balkans. Foreign Policy News, http://foreignpolicynews.org/2015/06/12/fighting-violent-extremism-in-thebalkans/, 2. 8. 2017.

Elbasani, Arolda i Roy, Olivier. 2015. The Revival of Islam in the Balkans - from Identity to Religiosity. Palgrave Macmillan. Basingstoke.

Fouéré, Erwan i Blockmans, Steven. 2017. The 'Berlin Process'for the Western Balkans - Is it delivering? CEPS. Brussels, https://www.ceps.eu/system/files/EF_SB_BalkansSummitBanner.pdf, 2. 8. 2017.

Hide, Enri. 2014. Islamic Extremism in the Balkans as a Geopolitical Instrument. Mediterranean Journal of Social Sciences. MCSER Publishing. Rome. 
Hillion, Christophe. 2010. The Creeping Nationalisation of the EU Enlargement Policy. Swedish Institute for European Policy Studies. Stockholm.

Jović, Dejan. 2015. Da li je EU jedina perspektiva regije? Autograf, 12. decembar, http:// www.autograf.hr/da-li-je-eu-jedina-perspektiva-regije/, 19. 8. 2017.

Lopandić, Duško. 2017. Političko i institucionalizovano vreme u EU i dinamika proširenja Unije. Emins, 10. jul, http://www.emins.org/srpski/research-results/article/politicko-i-institucionalizovano-vreme-u-eu-i-dinamika-prosirenja-unije, 18. 8. 2017.

Minić, Jelica. 2015. Promenjeni kontekst proširenja Evropske unije, šta da se radi? Izazovi spoljne politike Srbije - Zbornik radova. Evropski pokret u Srbiji. Beograd.

Miščević, Tanja. 2016. Sedam decenija ideje EU - kako dalje ili kako nazad? Spoljnopolitičke sveske 03/2016. Fondacija Fridrih Ebert. Beograd.

O’Brennan, John. 2006. The Eastern Enlargement of the European Union. Routledge. New York.

Panagiotou, Ritsa. 2014. The New Environment of EU Enlargement: The Impact of Economic Crisis on the Western Balkans and their EU Accession Prospects. Contemporary Southeastern Europe, 1 (1): 33-57.

Perkučin, Jovana i Novaković, Igor. 2017. An analysis of Serbia's compliance with EU foreign policy declarations and measures in 2016. ISAC. Beograd.

Ratchev, Valeri i Slavkova, Louisa. 2017. NATO in Southeast Europe: A Harbinger of Democracy? Friedrich-Ebert-Stiftung Dialogue Southeast Europe. Sarajevo.

Reljić, Dušan. 2016. Western Balkan's EU path: political and economic deadlocks. EWB, https://europeanwesternbalkans.com/2016/02/16/western-balkans-eu-pathpolitical-and-economic-deadlocks/.

Schneider, Christina J. 2009. Conflict, Negotiation and European Union Enlargement. Cambridge University Press. Cambridge.

Sjursen, Helene. 2007. Questioning EU Enlargement - Europe in Search of Identity. Routledge. Oxon.

Solioz, Christophe. 2014. The EU: wider and deeper with the Balkans, Open Democracy, https://www.opendemocracy.net/can-europe-make-it/christophe-solioz/eu-widerand-deeper-with-balkans, 17. 8. 2017.

Subotić, Jelena. 2011. Europe is a State of Mind: Identity and Europeanization in the Balkans. International Studies Quarterly, 55: 309-330.

Wallden, Axel Sotiris, 2017. The Demise of the Enlargement Policy. ELIAMEP. Athens. Wither, James Kenneth. 2015. Salafi-Jihadists: a Threat to the Western Balkans? Study Group Regional Stability in South East Europe. Beograd. 


\section{Drugi izvori}

Court of Justice of the EU. 2017. "Advocate General's Opinion in Cases C-643/15 and C-647/15 of Slovakia and Hungary v Council", 26 July, https://curia.europa.eu/ jcms/upload/docs/application/pdf/2017-07/cp170088en.pdf, 14. 8. 2017.

European Commission. 2003. "Thessaloniki Summit Declaration", 21 June, http://europa.eu/rapid/press-release_PRES-03-163_en.htm.

European Commission. 2014. "Statement - 10th anniversary of 2004 enlargement", 30 April, europa.eu/rapid/press-release_STATEMENT-14-143_en.pdf.

European Commission. 2016. "Albania 2016 Report", accompanying the Communication from the Commission to the European Parliament, the Council, the European Economic and Social Committee and the Committee of the Regions $\operatorname{COM}(2016)$ 715 final\}, 9 November, https://ec.europa.eu/neighbourhood-enlargement/sites/near/files/pdf/key_documents/2016/20161109_report_albania.pdf, 17. 8. 2017.

European Commission. 2016a. "The former Yugoslav Republic of Macedonia 2016 Report", accompanying the Communication from the Commission to the European Parliament, the Council, the European Economic and Social Committee and the Committee of the Regions, \{COM(2016) 715 final $\}, 9$ November, https://ec.europa.eu/ neighbourhood-enlargement/sites/near/files/pdf/key_documents/2016/20161109_ report_the_former_yugoslav_republic_of_macedonia.pdf, 10. 8. 2017.

European Court of Auditors. 2016. "EU pre-accession assistance for strengthening administrative capacity in the Western Balkans: A meta-audit 2016", Luxembourg, https://www.eca.europa.eu/Lists/ECADocuments/SR16_21/SR_WESTERN-BALKANS_EN.pdf.

European Council. 2016. "Public Opinion in the European Union" https://ec.europa. eu/commfrontoffice/publicopinion/index.cfm/ResultDoc/download/DocumentKy/79408, November 2016.

Eur-lex. 2000. "Council Joint Action 2000/717/CFSP of 16 November 2000 on the Holding of a Meeting of Heads of State or of Government in Zagreb" (Zagreb Summit 2000a), OJ 2000 L290, 17 November, http://eur-lex.europa.eu/legal-content/en/TX $\mathrm{T} /$ ? uri=CELEX:32000E0717\&qid=1500990135048.

Gallup. 2017. "Western Balkans benefit of joining EU”, Galupovo istraživanje u državama Zapadnog Balkana o koristima ulaska u EU - jul 2017, http://www.gallup.com/ poll/213899/western-balkans-benefit-joining.aspx, 20. 8. 2017.

Govor komesara za proširenje i susjedsku politiku Štefana Filea, http://europa.eu/rapid/ press-release_SPEECH-14-667_en.htm, 27. 7. 2017.

Govor Ahmeta Davutoglua na Oksfordu o međunarodnoj ulozi Turske, 30. april 2010, https://www.sant.ox.ac.uk/sites/default/files/reportfromtfpconf.pdf. 


\title{
Aleksandar Andrija Pejović \\ VARIABLE REALITY OF THE WESTERN BALKANS IN THE CONTEXT OF THE EUROPEAN INTEGRATION
}

\begin{abstract}
Summary
This article deals with the future of the Western Balkans in the light of a number of different factors that are not solely and purely connected to the countries of the region. Although the very process of integration into the EU is predominantly dependant on the readiness and the ability of the candidate and potential candidate countries to implement all the needed reforms, transpose the acquis and achieve the so-called European standard in legislation and in practice, the process is not being conducted in a vacuum. First of all, we should bear in mind that the development of the situation within the EU shall have crucial impact on the speed, depth and quality of the entrance of the remaining Balkan countries into the Union. Apart from that, we cannot ignore the influences of the third actors, which have become more visible and acute in the region. The EU and its Member States are the ones that define and set up the rules, therefore they bear most of the responsibility for the Enlargement Policy. Laggardness in reforms, EU crisis management, a stronger or weaker role of the third actors - all this shall determine what kind of process of European integration we shall have in the next years, and in line with it, the manner in which the process shall influence the stability and future of the enlargement countries. In this context, the Western Balkans simultaneously lives in variable realities that bring different outcomes and possibilities. This article, apart from the presentation of the situation in the Western Balkans, offers possible scenarios for the future.
\end{abstract}

Keywords: European Union, Enlargement Policy, Western Balkans, Third Actors, European integration

\footnotetext{
Aleksandar Andrija Pejović je doktorand na Pravnom fakultetu Univerziteta u Beogradu i nekadašnji ministar evropskih poslova Crne Gore i glavni pregovarač za vođenje pregovora Crne Gore s EU.

Kontakt: Aleksandar Andrija Pejović, Pravni fakultet, Univerzitet u Beogradu, Bulevar kralja Aleksandra 67, 11000 Beograd, Srbija.

E-mail: aleksandar.andrija@gmail.com
} 